\title{
Okul öncesi öğretmen adaylarının kimya, fizik ve biyoloji kavramlarına yönelik metaforik algıları
}

\author{
Pre-service early childhood education teachers' metaphorical perceptions towards \\ chemistry, physics and biology
}

\author{
Gonca HARMAN* \\ Aytekin ÇÖKELEZ ${ }^{* *}$
}

\begin{abstract}
Öz
$\mathrm{Bu}$ çalışma ile okul öncesi öğretmen adaylarının kimya, fizik ve biyoloji kavramlarına yönelik metaforik algılarının incelenmesi amaçlanmıştır. Çalışmaya okul öncesi eğitimi anabilim dalı 4. sınıfta öğrenim görmekte olan 70 öğretmen adayı katılmıştır. Öğretmen adaylarından kimya, fizik ve biyolojinin neye benzediğini gerekçeli olarak ifade etmeleri istenmiştir. Çalışmadan elde edilen veriler içerik analiz yöntemi ile çözümlenmiştir. Öğretmen adaylarının belirttikleri metaforlar olumlu, olumsuz ve nötr olmak üzere kategorize edilmiştir. Çalışma sonucunda olumlu metaforların sırası ile biyoloji, fizik ve kimya kavramlarına ilişkin olduğu belirlenmiştir. Okul öncesi öğretmen adaylarının biyolojiye yönelik algılarının fizik ve kimyaya yönelik algılarından daha olumlu olduğu görülmüştür. Kimya, biyoloji ve fizik için olumlu metaforların yaşam ve doğa ile iç içe, nötr metaforların konu ve içerik, olumsuz metaforların ise zor ve karmaşık kategorilerinde yoğunlaştığı saptanmıştır. Okul öncesi öğretmen adaylarının kimya, fizik ve biyoloji kavramları için zihinlerinde beliren ilk imgelerin kimya için periyodik cetvel ve element; fizik için basit makineler, kuvvet, hareket, hız, ivme, kütle, hacim, yoğunluk, yer çekimi; biyoloji için canlılar, bölünmeler, hücre, sistemler, fotosentez olduğu saptanmıştır.
\end{abstract}

Anahtar Kelimeler: Metafor, kimya, fizik, biyoloji, okul öncesi öğretmen adayı.

\begin{abstract}
The purpose of this study was to determine pre-service early childhood education student teachers' metaphorical perceptions towards chemistry, physics and biology. 70 pre-service early childhood education student teachers studying in the 4th grade at the department of early childhood education participated in this study. The participants were asked to express

** Doç. Dr., İstanbul Teknik Üniversitesi, Fen Edebiyat Fakültesi, İnsan ve Toplum Bilimleri Bölümü,
\end{abstract}

* Dr., e-posta: goncaharman@hotmail.com e-posta: cokelez@itu.edu.tr 
what chemistry, physics and biology look like. Collected data were analyzed by content analysis method. Pre-service early childhood education student teachers' metaphors were categorized into positive, negative and neutral. Results of the study showed that pre-service early childhood education student teachers have positive perceptions towards biology, physics and chemistry. According to the results of this study, pre-service early childhood education teachers' perceptions towards biology were more positive than their perceptions towards physics and chemistry. Positive metaphors about chemistry, physics and biology were categorized mostly as life and nature; neutral metaphors about chemistry, physics and biology were categorized mostly as subject and content; negative metaphors about chemistry, physics and biology were categorized mostly as difficult and complex. The results showed that when the preservice teachers think about chemistry, the words "periodic table and elements" come to their minds at first. The words "simple machines, force, motion, velocity, acceleration, mass, volume, density, gravity" come to their minds at first when they think about physics. The words "live, divisions, cells, systems, photosynthesis" come to their minds at first when they think about biology.

Keywords: Metaphor, chemistry, physics, biology, pre-service early childhood education teachers.

\section{Giriş}

Okul öncesi dönemde çocuklar keşfetmek ve öğrenmek için doğal bir eğilime sahiptir ve yaşam boyu devam edecek olan öğrenme bu yaşlarda başlamaktadır. Çocuğun bilişsel, dil, motor, sosyal ve duygusal gelişimi için güçlü bir zemin oluşturan beyin gelişiminin ve sinaptik bağlantıların kurulma oranının en yoğun ve hızlı yaşandığı dönem okul öncesi dönemdir. Bundan dolayı çocuklar özellikle yaşamın ilk altı yılında çok hızlı gelişirler ve bu yıllar okul öncesi dönem olarak adlandırılır (Çamlıbel-Çakmak, 2014). Okul öncesi dönem birçok becerinin temellerinin atıldı̆̆ 1 kritik eğitim dönemlerini kapsamaktadır. Fen eğitimi de bu kritik dönemin bir parçasıdır. Çocuk doğuştan sahip olduğu merak duygusuyla doğal çevresi ile etkileşme geçmektedir. Bu andan itibaren çocuğun fenle olan ilişkisi başlamakta ve bu ilişki tüm yaşamı boyunca sürmektedir (Yaşar, 1993). Fenin erken yaşlardaki önemi okul öncesi öğretmenlerinin fenin birçok alanındaki (kimya, fizik, biyoloji) bilgilerinin yeterli olmasını gerektirmektedir (Kallery, 2004). Okul öncesi öğretmen adaylarının bilgilerinin yeterli olmasının yanı sıra fenin farklı alanlarına ilişkin algılarının da olumlu olması beklenmektedir. Bu bağlamda okul öncesi öğretmenlerinin fenin farklı alanlarına yönelik algılarının belirlenmesi önemlidir. Bu amaçla metaforlardan yararlanılabilir.

Metaforlar, bir kavramın bireyler tarafından nasıl algılandığı ile ilgili fikir sahibi olmaya yardımcıdır (Cerit, 2008; Girmen, 2007; Gürbüzoğlu-Yalmancı ve Aydın, 2013). Bilinen bir kavram ya da durumdan yararlanılarak bilinmeyen bir kavram ya da durumla ilgili olarak açıklamalar yapabilme imkânı sunan metaforlar (Dönmez-Usta ve Ültay, 2015) bilinen bir alandan genellikle bilinmeyen bir alana bilginin transfer edilmesidir (Soysal ve Afacan, 2012). Ayrıca kavram yanılgılarının var olup olmadığının belirlenebilmesi bağlamında öğretmen 
adaylarının kullandıkları metaforların saptanması mevcut yanılgılarını gelecekte ders verecekleri öğrencilere aktarmalarını önleme hususunda da önem taşımaktadır (GürbüzoğluYalmancı ve Aydın, 2013).

Alanyazın incelendiğinde okul öncesi öğretmen adaylarının okul öncesi eğitim (ErtürkKara, 2014), okul öncesi eğitim öğretmeni (Giren, 2015; Serhatlığlu, 2014), çocuk (Akınc1Demirbaş, 2015; Ergin, Şahin ve Erişen, 2013; Şimşek ve Bildirici, 2016), müdür (Pesen, Kara ve Gedik, 2015), okul yöneticisi (Zembat, Tunçeli ve Akşin, 2015), yaratıcılık (Pekdoğan ve Konak, 2015; Şahin-Zeteroğlu, Doğan ve Taner-Derman, 2012; Tok, 2015), bilim ve bilim insanı (Şenel ve Aslan, 2014), demokrasi (Güder-Yağan ve Yıldırım, 2014), müzik (Acay-Sözbir ve ÇamlıbelÇakmak, 2016; Koca, 2012), kimya (Dönmez-Usta ve Ültay, 2015); okul öncesi öğretmenlerinin çocuk (Kuyucu, Şahin ve Kapıcıoğlu, 2013), okul öncesi dönem çocuğu için oyun (Giren, 2016), oyuncak (Giren ve Durak, 2015), veli (Neslitürk, Çamlıbel-Çakmak ve Asar, 2014) olmak üzere çeşitli kavramlarla ilgili algılamalarının metaforlar aracıl lğ̆ı ile saptandığı çalışmalar mevcuttur. Buna karşın okul öncesi öğretmen adaylarının kimya, fizik ve biyoloji kavramlarına yönelik metaforik algılarını bir arada inceleyen bir çalışma bulunmamaktadır. Fenin farklı alanlarına yönelik metaforların incelendiği araştırmalardan Dönmez-Usta ve Ültay (2015) tarafından yapılan çalışmada okul öncesi öğretmen adaylarının kimya kavramına ilişkin ifade ettikleri olumlu ve olumsuz metafor sayılarının birbirine yakın olduğu ortaya koyulmuştur. Derman (2014) tarafından yapılan çalışmada lise öğrencilerinin kimya kavramına ilişkin metaforları incelenmiş ve çoğunlukla "Kimyanın yapısı ve işleyiş̧" kategorisinin çok sayıda metaforla temsil edildiği saptanmıştır. Ayrıca çalışmada "Sevilmeyen, zor ve karışık bir ders olarak kimya" kategorisinin temsil yüzdesinin "Sevilen, eğlenceli, kavranabilir bir ders olarak kimya" kategorisinin temsil yüzdesinden daha fazla olduğu ortaya koyulmuştur. Derman (2014) bu sonucun lise öğrencilerinin kimya dersine yönelik tutumları bağlamında olumlu bir durum olmadığını vurgulamıştır. Gürbüzoğlu-Yalmancı ve Aydın (2013) tarafından yapılan çalışmada fen bilgisi ve sınıf öğretmeni adaylarının biyoloji kavramını hayat metaforunu ifade ederek yaşamın kendisi ile ilişkilendirdikleri saptanmıştır. Bu bulgu öğretmen adaylarının biyolojinin içerik ve işlev olarak hayatı yansıttı̆̆ını düşündüklerini göstermektedir. Bunun yanı sıra çok az sayıda öğretmen adayının ise olumsuz metaforlar oluşturduğunu ortaya koymuşlardır. $\mathrm{Bu}$ nedenle çalı̧̧ma sonucunda öğretmen adaylarının "biyoloji” kavramı hakkında olumlu yargıları olduğunu vurgulamışlardır. Yapıcı (2015) tarafından yapılan çalışmada lise öğrencilerinin önemli bir bölümünün biyolojiyi yaşamın kaynağı-yaşamın kendisi, değişen ve gelişen, yaşam alanı ve gereksinim olarak nitelendirdikleri ortaya koyulmuştur. Lise öğrencilerinin biyoloji ile ilgili olumlu görüşe sahip oldukları ifade edilmiştir. Bunun yanı sıra Yapıcı (2015) çalışmasında az sayıda da olsa bazı öğrencilerin olumsuz tutum ve görüşlerini ortaya koyan metaforlar oluşturduklarını da belirtmiştir. Ulukök, Bayram ve Selvi (2015) tarafından yapılan çalışmada fen bilgisi öğretmen adaylarının biyoloji kavramına ilişkin olumlu ve olumsuz metaforlar oluşturdukları, bununla birlikte olumlu algıların daha fazla olduğu ortaya koyulmuştur. $\mathrm{Bu}$ durum üzerinde biyoloji konularının günlük yaşamla ilgili olması, biyolojiden zevk almaları, 
sevmeleri ve eğlenceli bir ders olarak görmelerinin etkili olabileceği ifade edilmiştir. Az sayıda olmakla birlikte bazı öğretmen adaylarının olumsuz görüşe sahip olmalarının meslek hayatlarında karşılarına bir engel olarak çıkacağı belirtilmiştir.

Öğretmen adaylarının olumlu/olumsuz metafor geliştirmelerinde fene yönelik tutumlarının etkili olduğu düşünülebilir (Osborne, Simon ve Collins, 2003). Bu düşünceden hareketle öğretmen adaylarının kimya, fizik ve biyoloji kavramlarına ilişkin oluşturacakları metaforların da kimya, fizik ve biyolojiye yönelik tutumlarını ortaya koyma bağlamında son derece önemli olduğu düşünülmektedir. Ayrıca çalışmanın alanyazında okul öncesi son sınıf öğretmen adaylarının kimya, fizik ve biyoloji kavramlarına ilişkin metaforik algılarını birlikte inceleyen ilk çalışma olması nedeni ile önemli olduğu düşünülmektedir.

Bu gereklilikten hareketle aşağıdaki sorulara cevap aranmıştır:

1. Okul öncesi öğretmen adaylarının kimya kavramına yönelik ifade ettikleri metaforlar nelerdir?

2. Okul öncesi öğretmen adaylarının fizik kavramına yönelik ifade ettikleri metaforlar nelerdir?

3. Okul öncesi öğretmen adaylarının biyoloji kavramına yönelik ifade ettikleri metaforlar nelerdir?

4. Okul öncesi öğretmen adaylarının kimya, fizik ve biyoloji kavramlarına yönelik ifade ettikleri metaforlar ile bu kavramlara ilişkin tutumları arasında nasıl bir ilişki vardır?

\section{Yöntem}

Çalışmada okul öncesi öğretmen adaylarının kimya, fizik ve biyoloji kavramlarına ilişkin oluşturdukları metaforları incelemek amacıyla nitel araştırmalarda kullanılan olgu bilim (fenomenoloji) deseni kullanılmıştır. Olgu bilim (fenomenoloji) deseni farkında olmamıza rağmen derinlemesine ve ayrıntılı bir anlayışa sahip olmadığımız olgular üzerinde yoğunlaşmaktadır. Olgular yaşadığımız dünyada olgular, deneyimler, algılar, yönelimler, kavramlar ve durumlar gibi çeşitli biçimlerde günlük yaşantımızda karşımıza çıkmaktadır. $\mathrm{Bu}$ karşılaşmalar olguları tam olarak anladı̆̆ımızı göstermez. Tamamen yabancı olmamakla birlikte anlamlarını tam olarak kavrayamadığımız olguları araştırmayı amaçlayan çalışmalar için olgubilim (fenomenoloji) uygun bir araştırma desenidir (Yıldırım ve Şimşek, 2011).

\section{Çalışma grubu}

Çalışmaya Eğitim Fakültesi Okul Öncesi Eğitimi Anabilim Dalında dördüncü sınıfta öğrenim gören 70 okul öncesi öğretmen adayı katılmıştır. 


\section{Veri toplama aracı}

Çalışmaya katılan öğretmen adaylarının kimya, fizik ve biyoloji kavramlarına yönelik algılarını belirlemek için "Kimya ......... gibidir, çünkü.................."; "Fizik

gibidir, çünkü.................."; "Biyoloji ......... gibidir, çünkü................." cümlelerini tamamlamaları ve kimya, fizik, biyoloji kavramları için zihinlerinde beliren ilk üç kelimeyi yazmaları istenmiştir.

\section{Verilerin analizi}

Çalışma kapsamında elde edilen veriler Saban (2008), Yapıcı (2015) ve Ulukök, Bayram ve Selvi (2015) tarafından yapılmış olan çalışmalarda kullanılan (1) adlandırma, (2) tasnif etme, (3) kategori geliştirme, (4) geçerlik ve güvenirliği sağlama ve (5) verileri bilgisayar ortamına aktarma aşamaları takip edilerek analiz edilmiştir.

Adlandırma aşamasında okul öncesi öğretmen adaylarının ifade ettikleri metaforlar gerekçeleri ile birlikte Excell tablosuna yazılmış ve ifade edilen metaforlar ile metafor-gerekçe uygunluğu incelenmiştir.

Tasnif etme (eleme ve arıtma) aşamasında okul öncesi öğretmen adaylarının metaforları konu, kaynak ve konu ile kaynak arasındaki ilişki bağlamında analiz edilmiştir. Kimya kavramı için 3, fizik kavramı için 8 ve biyoloji kavramı için 11 form ifade edilen metaforlar ile gerekçelerinin anlamsız olması nedeni ile çalışma kapsamına alınmamıştır. Elemeden sonra kimya kavramı için 67 formdan 52, fizik kavramı için 62 formdan 50 ve biyoloji kavramı için 59 formdan 36 metafor elde edilmiştir.

Kategori geliştirme aşamasında okul öncesi öğretmen adaylarının ifade ettikleri metaforlar ortak özellikleri açısından incelenmiştir. Kimya kavramı için 18, fizik kavramı için 14 ve biyoloji kavramı için 12 farklı kategori geliştirilmiştir.

Geçerlik ve güvenirliği sağlama aşamasında kategoriler altına yerleştirilen metaforların ilgili kategorileri temsil etme uygunluğunu belirlemek amacı ile iki araştırmacının birbirinden bağımsız olarak belirledikleri kategoriler karşılaştırılmıştır. Görüş birliği ve görüş ayrılığ sayıları belirlenmiştir. Veri analizinin güvenirliği, Miles ve Huberman’ın (1994) Güvenirlik = Görüş Birliği \[Görüş Birliği + Görüş Ayrılığı] X 100 formülü kullanılarak hesaplanmış ve güvenirlik değeri \% 90 olarak bulunmuştur. Bulunan değer \%70'in üzerinde olup bu çalışma için güvenilir olarak kabul edilmiştir (Miles ve Huberman, 1994).

Verileri bilgisayar ortamına aktarma aşamasında metafor sayıları belirlenip kategorilerin oluşturulmasının ardından veriler bilgisayar ortamına aktarılarak katılımcı sayılarını temsil eden frekanslar hesaplanmıştır. 


\section{Bulgular}

Okul öncesi öğretmen adaylarının kimya kavramına ilişkin ifade ettikleri olumlu metaforlar Tablo 1'de verilmiştir.

Tablo I

Okul Öncesi Öğretmen Adaylarının Olumlu Metaforları (Kimya)

\begin{tabular}{|c|c|c|c|}
\hline Kategoriler & Olumlu metafor & Frekans & Çünkü \\
\hline \multirow[t]{3}{*}{ Yaşam ve doğa ile iç içe } & Yaşam & 5 & yaşamin özüdür. Her şey bu özden oluşur. \\
\hline & Doğa & 2 & doğadaki çoğu öğe kimyadan oluşur. \\
\hline & Toplam & 7 & \\
\hline \multirow[t]{5}{*}{ Eğlenceli } & Gökkuşağı & 2 & $\begin{array}{l}\text { kendinde her rengi ve eğlenceyi barındırır. Bir o kadar da } \\
\text { gizemlidir. }\end{array}$ \\
\hline & Oyuncak & 1 & eğlencelidir. \\
\hline & Oyun & 1 & eğlencelidir. \\
\hline & Park & 1 & farklı maddelerle eğlenerek öğrenirsin. \\
\hline & Toplam & 5 & \\
\hline \multirow{5}{*}{$\begin{array}{l}\text { Değişen, ilerleyen ve } \\
\text { yenilikçi }\end{array}$} & Canlı & 1 & değişen bir yapısı vardır. \\
\hline & Aşçı & 1 & yeni şeyleri dener. \\
\hline & İplik & 1 & çözdükçe peşi gelir. Bir ipi çözmek gibidir. \\
\hline & Müzik & 1 & araştırdıkça yeni şeyler ortaya çıkar. \\
\hline & Toplam & 4 & \\
\hline \multirow[t]{3}{*}{ İhtiyaç } & Oksijen & 2 & nefes almak için gereklidir. Olmazsa olmazdır. \\
\hline & Beyin & 1 & gereklidir. \\
\hline & Toplam & 3 & \\
\hline \multirow[t]{4}{*}{ Üretken } & İçecek & 1 & bir şeyleri karıştırıp başka şeyler yapıyoruz. \\
\hline & Tepkime & 1 & birleşip ortaya bir ürün çıkarır. \\
\hline & Yemek yapmak & 1 & birleşerek çoğalır. \\
\hline & Toplam & 3 & \\
\hline \multirow[t]{3}{*}{ Kapsamlı } & Yemek & 1 & içinde her şey vardır. \\
\hline & Denge & 1 & her şey ona bağhldır. \\
\hline & Toplam & 2 & \\
\hline Faydalı & İlaç & 1 & iyi kullanilırsa insan sağllğına faydalıdır. \\
\hline Bütüncül & Așk & 1 & iki molekül arasındaki bağ gibidir. \\
\hline Öğrenme kolaylı̆̆ 1 & Sihir & 1 & kolay ögrrenilir. \\
\hline
\end{tabular}

Tablo incelendiğinde 27 okul öncesi öğretmen adayının kimya kavramına ilişkin olumlu metaforlar ifade ettikleri; olumlu metaforların daha çok yaşam ve doğa ile iç içe (7), eğlenceli (5), değişen, ilerleyen ve yenilikçi (4), ihtiyaç (3), üretken (3) ve kapsamlı (2) kategorilerinde yoğunlaştığ 1 görülmektedir. 
Okul öncesi öğretmen adaylarının kimya kavramına ilişkin ifade ettikleri nötr metaforlar Tablo 2'de verilmiştir.

\section{Tablo 2}

Okul Öncesi Öğretmen Adaylarının Nötr Metaforları (Kimya)

\begin{tabular}{|c|c|c|c|}
\hline Kategoriler & Nötr metafor & Frekans & Çünkü \\
\hline \multirow[t]{3}{*}{ Konu ve içerik } & Atom & 3 & atomu inceler. \\
\hline & $\mathrm{Su}$ & 2 & incelediği her madde doğadan, dolayısıyla doğaldır. \\
\hline & Toplam & 5 & \\
\hline \multirow[t]{5}{*}{ Uygulama } & Araştırma & 1 & parçalara ayırır. \\
\hline & Bulmaca & 1 & çözmek gerekir. \\
\hline & Formül & 1 & işlem vardır. \\
\hline & Yapboz & 1 & deneyler vardır. \\
\hline & Toplam & 4 & \\
\hline \multirow[t]{3}{*}{ Kapsamli } & Deniz & 1 & uçsuz bucaksızdır. \\
\hline & İnsan & 1 & konuları çok çeşitlidir. \\
\hline & Toplam & 2 & \\
\hline \multirow[t]{4}{*}{ Disiplinler arası ilişki } & Fizik & 1 & birbirlerine benzerler. \\
\hline & Matematik & 1 & formüller vardır. \\
\hline & Toplam & 2 & \\
\hline & TOPLAM & 13 & \\
\hline
\end{tabular}

Tablo incelendiğinde 13 okul öncesi öğretmen adayının kimya kavramına ilişkin nötr metaforlar ifade ettikleri; nötr metaforların konu ve içerik (5), uygulama (4), kapsamlı (2) ve disiplinler arası ilişki (2) kategorilerinde yoğunlaştığı görülmektedir.

Okul öncesi öğretmen adaylarının kimya kavramına ilişkin ifade ettikleri olumsuz metaforlar Tablo 3'te verilmiştir. 
Gonca HARMAN • Aytekin ÇÖKELEZ

Tablo 3

Okul Öncesi Öğretmen Adaylarının Olumsuz Metaforları (Kimya)

\begin{tabular}{|c|c|c|c|}
\hline Kategoriler & $\begin{array}{l}\text { Olumsuz } \\
\text { metafor }\end{array}$ & Frekans & Çünkü \\
\hline \multirow[t]{13}{*}{ Zor ve karmaşık } & Zor şeyler & 3 & konuları karmaşıktır. \\
\hline & Çorba & 2 & karışıktır. \\
\hline & Kadın & 2 & anlaşılması zordur. \\
\hline & Atom & 1 & zor öğrenilir. \\
\hline & İnsan & 1 & insanlar karışıktır. \\
\hline & Dünya & 1 & karışılktır. \\
\hline & Gereksiz şeyler & 1 & hep zordur. \\
\hline & Labirent & 1 & karışıktır. \\
\hline & Problem & 1 & anlaşılması güçtür. \\
\hline & Renk & 1 & renkler gibi karışıktır. \\
\hline & Sarmaşık & 1 & karışılk yapılardan oluşur. \\
\hline & Yumak & 1 & karışıktır. \\
\hline & Toplam & 16 & \\
\hline \multirow[t]{5}{*}{ Tehlikeli } & Bomba & 2 & doğru kullanılmadığında patlayabilir. \\
\hline & Asit & 1 & yakıcıdır. \\
\hline & Aşk & 1 & beklemediğin olumsuz tepkimeler ortaya çıkabilir. \\
\hline & Ateş & 1 & yanlış bir şey yaparsan elin yanabilir. \\
\hline & Toplam & 5 & \\
\hline \multirow[t]{5}{*}{ Rahatsız edici } & Limon & 1 & ekşidir. \\
\hline & Tuz & 1 & fazlası tat kaçırır. \\
\hline & Mide & 1 & başka maddeler bir madde ile karşınca onu bozabilir. \\
\hline & Yumurta & 1 & dışı güzel görünse de içi çürük olabilir. \\
\hline & Toplam & 4 & \\
\hline Gereksiz & Dalak & 1 & gereksizdir. \\
\hline \multirow[t]{2}{*}{ Soyut } & Hayalet & 1 & var olduğunu bilirsin ama göremezsin. \\
\hline & TOPLAM & 27 & \\
\hline
\end{tabular}

Tablo incelendiğinde 27 okul öncesi öğretmen adayının kimya kavramına ilişkin olumsuz metaforlar ifade ettikleri; olumsuz metaforların daha çok zor ve karmaşık (16), tehlikeli (5) ve rahatsız edici (4) kategorilerinde yoğunlaştı̆̆ 1 görülmektedir.

Okul öncesi öğretmen adaylarının fizik kavramına ilişkin ifade ettikleri olumlu metaforlar Tablo 4’te verilmiştir. 


\section{Tablo 4}

\section{Okul Öncesi Öğretmen Adaylarının Olumlu Metaforları (Fizik)}

\begin{tabular}{|c|c|c|c|}
\hline Kategoriler & Olumlu metafor & Frekans & Çünkü \\
\hline \multirow[t]{5}{*}{ Yaşam ve doğa ile iç içe } & Yaşam & 4 & yaşamın her alanında fizik vardır. \\
\hline & Denge & 2 & her şey ona bağglıdır. \\
\hline & Çekirdek & 1 & yaşamin merkezindedir. \\
\hline & Doğa & 1 & doğayı yansıtır. \\
\hline & Toplam & 8 & \\
\hline \multirow[t]{5}{*}{ Denge ve düzen } & Denge & 1 & her şey dengededir. \\
\hline & Karmaşık ortam & 1 & $\begin{array}{l}\text { ilk başta karışılktır. Taki ortam karışıı olunca nasıl ki toplarsak } \\
\text { düzelir. Fizikte öyle çözdükçe karmaşıklık gider. }\end{array}$ \\
\hline & Kulak & 1 & dengededir. \\
\hline & Terazi & 1 & kefeleri dengeler. \\
\hline & Toplam & 4 & \\
\hline \multirow[t]{5}{*}{ Dikkat ve güdü } & Akıl & 1 & her şeyi kavramak için gereklidir. \\
\hline & Beyin & 1 & zeka ister. \\
\hline & Araba sürmek & 1 & dikkat gerektirir. \\
\hline & Hareket & 1 & harekete geçmemizi sağlar. \\
\hline & Toplam & 4 & \\
\hline \multirow[t]{4}{*}{ Eğlenceli } & Oyun & 2 & eğlencelidir. \\
\hline & $\begin{array}{l}\text { Zekâ küpü } \\
\text { oyuncağ1 }\end{array}$ & 1 & çözdükçe zevk alırsin. \\
\hline & At & 1 & ata önce binmeye korkarsin binince de inmek istemezsin. \\
\hline & Toplam & 4 & \\
\hline \multirow{4}{*}{$\begin{array}{l}\text { Değișen, ilerleyen ve } \\
\text { yenilikçi }\end{array}$} & Top & 1 & sürekli hareket halindedir. \\
\hline & Çocuk & 1 & aşama aşama büyüyerek ilerler. \\
\hline & Denklem & 1 & çözdükçe farkh çözümler verir. \\
\hline & Toplam & 3 & \\
\hline \multirow[t]{3}{*}{ İhtiyaç } & Yaşam kuralları & 1 & $\begin{array}{l}\text { fizik kuralları olmazsa yaşam olmazdı ya da fizik yaşamsal } \\
\text { dengedir. }\end{array}$ \\
\hline & $\begin{array}{l}\text { Günlük yaşamın } \\
\text { yardımcısı }\end{array}$ & 1 & iş-makine gibi konularla ilgilenir. \\
\hline & Toplam & 2 & \\
\hline $\begin{array}{l}\text { Keşfetme ve } \\
\text { araştırmaya açık }\end{array}$ & Dünya & 2 & keşfedilmeyen bir şeyler her zaman mevcuttur. \\
\hline \multirow[t]{2}{*}{ Anlaşlır } & Kolay şeyler & 2 & konuları daha anlaşılırdır. \\
\hline & TOPLAM & 29 & \\
\hline
\end{tabular}

Tablo incelendiğinde 29 okul öncesi öğretmen adayının fizik kavramına ilişkin olumlu metaforlar ifade ettikleri; olumlu metaforların daha çok yaşam ve doğa ile iç içe (8), denge ve düzen (4), dikkat ve güdü (4), eğlenceli (4), değişen, ilerleyen ve yenilikçi (3), ihtiyaç (2) kategorilerinde yoğunlaştığı görülmektedir. 
Okul öncesi öğretmen adaylarının fizik kavramına ilişkin ifade ettikleri nötr metaforlar Tablo 5’te verilmiştir.

Tablo 5

Okul Öncesi Öğretmen Adaylarının Nötr Metaforları (Fizik)

\begin{tabular}{|c|c|c|c|}
\hline Kategoriler & Nötr metafor & Frekans & Çünkü \\
\hline \multirow[t]{9}{*}{ Konu ve içerik } & Güç & 3 & gücü inceler. \\
\hline & Dünya & 1 & dünyayı inceler. \\
\hline & Hareket & 1 & hareket fizikte temel konulardan biridir. \\
\hline & Kaldıraç & 1 & konusudur. \\
\hline & Yol & 1 & hız ve zaman ile ilgili konular vardır. \\
\hline & Öz kütle & 1 & konusudur. \\
\hline & Sayılar & 1 & matematiksel ifadelerle doludur. \\
\hline & Şekil & 1 & şekiller çizilir. \\
\hline & Toplam & 10 & \\
\hline \multirow{5}{*}{$\begin{array}{l}\text { Kapsamlı ve } \\
\text { disiplinler arası ilişki }\end{array}$} & Uzay & 2 & sonsuzdur. \\
\hline & Evren & 1 & çok geniş bir alandır. \\
\hline & Matematik & 1 & işlemler vardır. \\
\hline & Toplam & 4 & \\
\hline & TOPLAM & 14 & \\
\hline
\end{tabular}

Tablo incelendiğinde 14 okul öncesi öğretmen adayının fizik kavramına ilişkin nötr metaforlar ifade ettikleri; nötr metaforların daha çok konu ve içerik (10), kapsamlı ve disiplinler arası ilişki (4) kategorilerinde yoğunlaştığı görülmektedir.

Okul öncesi öğretmen adaylarının fizik kavramına ilişkin ifade ettikleri olumsuz metaforlar Tablo 6'da verilmiştir. 


\section{Tablo 6}

Okul Öncesi Öğretmen Adaylarının Olumsuz Metaforları (Fizik)

\begin{tabular}{|c|c|c|c|}
\hline Kategoriler & $\begin{array}{l}\text { Olumsuz } \\
\text { metaforlar }\end{array}$ & Frekans & Çünkü \\
\hline \multirow[t]{13}{*}{ Zor ve karmaşık } & Zor şeyler & 2 & karmaşıktır. \\
\hline & Ayna & 1 & insanın kendisini tanıyamaması kadar karışık bir yapısı vardır. \\
\hline & Çıkmaz sokak & 1 & zordur. \\
\hline & Dönme dolap & 1 & baş döndürür. \\
\hline & İşkence & 1 & yapamıyorum. \\
\hline & Kı̧̧ & 1 & zor geçer. \\
\hline & Korku & 1 & zor geliyor. \\
\hline & Kulaklık & 1 & $\begin{array}{l}\text { kulaklık nasıl cebe girdiğinde karmakarışık oluyorsa fiziğinde } \\
\text { içine girdiğinde karmakarışık olduğunu anlarsın. }\end{array}$ \\
\hline & Labirent & 1 & karmaşıktır. \\
\hline & Matematik & 1 & karmaşıktır. \\
\hline & Terazi & 1 & ağırdır. \\
\hline & Uzay & 1 & karmaşıktır. \\
\hline & Toplam & 13 & \\
\hline \multirow[t]{3}{*}{ Tehlikeli } & Elektrik & 2 & çarpar. \\
\hline & Ateş & 1 & yanina yaklaşılmamal, yakar. \\
\hline & Toplam & 3 & \\
\hline \multirow[t]{3}{*}{ Gereksiz } & Gereksiz şeyler & 1 & gerçek yaşamda hiçbir işe yaramaz. \\
\hline & Yabancı müzik & 1 & gereği yoktur. \\
\hline & Toplam & 2 & \\
\hline \multirow[t]{2}{*}{$\begin{array}{l}\text { Niteliklerini } \\
\text { kaybeden }\end{array}$} & Makine & 1 & kullandıkça ömrü tükenir. \\
\hline & TOPLAM & 19 & \\
\hline
\end{tabular}

Tablo incelendiğinde 19 okul öncesi öğretmen adayının fizik kavramına ilişkin olumsuz metaforlar ifade ettikleri; olumsuz metaforların daha çok zor ve karmaşık (13), tehlikeli (3) ve gereksiz (2) kategorilerinde yoğunlaştığ görülmektedir.

Okul öncesi öğretmen adaylarının biyoloji kavramına ilişkin ifade ettikleri olumlu metaforlar Tablo 7'de verilmiştir. 
Gonca HARMAN • Aytekin ÇÖKELEZ

\section{Tablo 7}

Okul Öncesi Öğretmen Adaylarının Olumlu Metaforları (Biyoloji)

\begin{tabular}{|c|c|c|c|}
\hline Kategoriler & Olumlu metafor & Frekans & Çünkü \\
\hline \multirow{8}{*}{$\begin{array}{l}\text { Yaşam ve doğa ile } \\
\text { iç içe }\end{array}$} & Yaşam & 6 & yaşamın ta kendisidir. \\
\hline & Ayna & 3 & doğayı yansıtır. Ayrıca kendini de görürsün. \\
\hline & Doğa & 3 & her yerdedir. Her şeyini onun içinden alır. \\
\hline & Dünya & 2 & dünyanın parçasıdır. Gerçektir. \\
\hline & Hücre & 1 & doğanın temelini oluşturur. \\
\hline & Toprak & 1 & her şey topraktan meydana gelir. \\
\hline & Yaşayan bilim & 1 & tüm canliları kapsar. \\
\hline & Toplam & 17 & \\
\hline \multirow[t]{4}{*}{ İhtiyaç } & $\mathrm{Su}$ & 2 & olmazsa yaşam olmaz. \\
\hline & Temiz hava & 1 & rahatlatır. \\
\hline & Yaşamak & 1 & olmazsa olmazdır. \\
\hline & Toplam & 4 & \\
\hline \multirow[t]{4}{*}{ Zevkli } & Müzik & 2 & dinledikçe güzellikleri fark edilir. \\
\hline & Eğlence & 1 & çok zevklidir. \\
\hline & Kahve içmek & 1 & keyiflidir. \\
\hline & Toplam & 4 & \\
\hline \multirow{4}{*}{$\begin{array}{l}\text { Değişen, ilerleyen ve } \\
\text { yenilikçi }\end{array}$} & Canlı & 1 & yaşayan bir bilimdir. \\
\hline & Değişim & 1 & sürekli yenilenir. \\
\hline & Dönüşüm & 1 & sürekli gelişir. \\
\hline & Toplam & 3 & \\
\hline \multirow[t]{3}{*}{ Düzenli } & Meyve tabağ 1 & 1 & konuları çeşit çeşittir ve bir araya gelince daha mükemmeldir. \\
\hline & İnsan & 1 & her şeyi sistemlidir. \\
\hline & Toplam & 2 & \\
\hline \multirow[t]{3}{*}{ Araştırmaya açık } & Bilim & 1 & araştırmacıdır. \\
\hline & Dedektif & 1 & her şeyin özünü araştırır. \\
\hline & Toplam & 2 & \\
\hline Etkileyici & Çiçek & 2 & rengarenktir. Güzeldir. \\
\hline Anlaşılır & Zevkli şeyler & 2 & anlaşılması kolaydır. \\
\hline \multirow[t]{2}{*}{ Eğlenceli } & Çocuk & 1 & hayat dolu ve eğlencelidir. \\
\hline & TOPLAM & 37 & \\
\hline
\end{tabular}

Tablo incelendiğinde 37 okul öncesi öğretmen adayının biyoloji kavramına ilişkin olumlu metaforlar ifade ettikleri; olumlu metaforların daha çok yaşam ve doğa ile iç içe (17), ihtiyaç (4), zevkli (4), değişen, ilerleyen ve yenilikçi (3), düzenli (2) ve araştırmaya açık (2) kategorilerinde yoğunlaştığg görülmektedir.

Okul öncesi öğretmen adaylarının biyoloji kavramına ilişkin ifade ettikleri nötr metaforlar Tablo 8'de verilmiştir. 


\section{Tablo 8}

Okul Öncesi Öğretmen Adaylarının Nötr Metaforları (Biyoloji)

\begin{tabular}{|c|c|c|c|}
\hline Kategoriler & Nötr metafor & Frekans & Çünkü \\
\hline \multirow[t]{8}{*}{ Konu ve içerik } & Yaşam & 8 & yaşamı anlatır. \\
\hline & Canlı & 3 & canlı bilimidir. \\
\hline & İnsan & 2 & organizmayı inceler. \\
\hline & Doğa & 1 & doğayı anlatır. \\
\hline & Gen & 1 & biyolojinin konusudur. \\
\hline & Oluş & 1 & var oluşu inceler. \\
\hline & Göz & 1 & varlikları, özelliklerini incelersin, hissedersin. \\
\hline & Toplam & 17 & \\
\hline \multirow[t]{4}{*}{ Kapsamlı } & Ăgaç & 1 & dallara ayrillr. \\
\hline & Vitaminler & 1 & içerisinde çeşitli konular vardır. \\
\hline & Toplam & 2 & \\
\hline & TOPLAM & 19 & \\
\hline
\end{tabular}

Tablo incelendiğinde 19 okul öncesi öğretmen adayının biyoloji kavramına ilişkin nötr metaforlar ifade ettikleri; nötr metaforların daha çok konu ve içerik (17) ve kapsamlı (2) kategorilerinde yoğunlaştığı görülmektedir.

Okul öncesi öğretmen adaylarının biyoloji kavramına ilişkin ifade ettikleri olumsuz metaforlar Tablo 9'da verilmiştir.

\section{Tablo 9}

Okul Öncesi Öğretmen Adaylarının Olumsuz Metaforları (Biyoloji)

\begin{tabular}{|c|c|c|c|}
\hline Kategoriler & Olumsuz metafor & Frekans & Çünkü \\
\hline \multirow[t]{4}{*}{ Zor ve karmaşık } & Kök & 1 & derinlere indikçe zorlaşır. \\
\hline & Sözel bir ders & 1 & ezber çoktur. \\
\hline & Zor şeyler & 1 & anlamıyorum. \\
\hline & TOPLAM & 3 & \\
\hline
\end{tabular}

Tablo incelendiğinde 3 okul öncesi öğretmen adayının biyoloji kavramına ilişkin olumsuz metaforlar ifade ettikleri; olumsuz metaforların zor ve karmaşık (3) kategorisinde olduğu görülmektedir.

Çalışma sonucunda kimya, fizik ve biyoloji kavramlarına ilişkin okul öncesi öğretmenleri tarafından belirtilen olumlu, nötr ve olumsuz metaforlar ve araştırmacılar tarafından oluşturulan kategorilere ilişkin frekans değerleri Tablo 10 'da verilmiştir. 
Gonca HARMAN • Aytekin ÇÖKELEZ

Tablo 10

Metafor Çeşidi ve Kategorilere Illişkin Frekans Değerleri

\begin{tabular}{lcccccccccc}
\hline & \multicolumn{3}{c}{ Öğretmen adayı (f) } & \multicolumn{3}{c}{ Metafor çeșidi (f) } & \multicolumn{3}{c}{ Kategori (f) } \\
\cline { 2 - 12 } & Kimya & Fizik & Biyoloji & Kimya & Fizik & Biyoloji & Kimya & Fizik & Biyoloji \\
\hline Olumlu metafor & 27 & 29 & 37 & 20 & 22 & 24 & 9 & 8 & 9 \\
\hline Nötr metafor & 13 & 14 & 19 & 10 & 11 & 9 & 4 & 2 & 2 \\
\hline Olumsuz metafor & 27 & 19 & 3 & 22 & 17 & 3 & 5 & 4 & 1 \\
\hline TOPLAM & $\mathbf{6 7}$ & $\mathbf{6 2}$ & $\mathbf{5 9}$ & $\mathbf{5 2}$ & $\mathbf{5 0}$ & $\mathbf{3 6}$ & $\mathbf{1 8}$ & $\mathbf{1 4}$ & $\mathbf{1 2}$ \\
\hline
\end{tabular}

Tablo incelendiğinde olumlu metaforların daha çok biyoloji kavramına ilişkin olduğu, fizik ve kimya kavramlarına ilişkin olumlu metafor sayılarının çok az bir farkla aynı olduğu; olumlu metafor çeşitlerinin kimya, fizik ve biyoloji olmak üzere üç kavram için de birbirine yakın olduğu, biyoloji kavramı için olumsuz metafor çeşidinin kimya ve fizik kavramlarına nazaran oldukça az olduğu görülmektedir. Buradan okul öncesi öğretmen adaylarının biyolojiye yönelik algılarının fizik ve kimyaya yönelik algılarından daha olumlu olduğu anlaşılmaktadır.

Okul öncesi öğretmen adaylarının kimya kavramına yönelik zihinlerinde beliren ilk imgeler Tablo 11'de verilmiştir.

\section{Tablo II}

\section{Okul Öncesi Öğretmen Adaylarının Kimya Kavramına Yönelik Zihinlerinde Beliren Illk Imgeler}

\begin{tabular}{|c|c|c|c|c|c|}
\hline İcerik/Konu & & & & & \\
\hline Periyodik cetvel & 17 & Kalsiyum & 1 & Tepkime & 10 \\
\hline Element & 17 & Uranyum & 1 & Oksitlenme & 1 \\
\hline Bileşik & 8 & Sodyum & 1 & Madde & 4 \\
\hline Molekül & 5 & Fosfat & 1 & Maddenin halleri & 4 \\
\hline İyon & 1 & Karbondioksit & 1 & Maddenin yapısı & 1 \\
\hline Ásit-baz & 7 & Karışım & 6 & Erime noktası & 1 \\
\hline Soygaz & 1 & Çözelti & 3 & Kütle & 1 \\
\hline Ametal & 1 & Átom & 14 & Yoğunluk & 1 \\
\hline $\mathrm{Su}$ & 6 & Elektron & 6 & Atom no & 1 \\
\hline Oksijen & 5 & Proton & 4 & Kütle no & 1 \\
\hline Karbon & 2 & Nötron & 2 & Katalizör & 1 \\
\hline Klor & 1 & En küçük parçacıl & 1 & & \\
\hline Uygulama & \multicolumn{4}{|c|}{$\begin{array}{l}\text { Günlük yașam } \\
\end{array}$} & \\
\hline Deney yapmak & \multicolumn{4}{|c|}{ Hayatın kendisi } & 2 \\
\hline Bilimsel araştırma yapmak & \multicolumn{4}{|c|}{ İlaç } & 2 \\
\hline Laboratuvar & \multicolumn{4}{|c|}{ Gübre } & 1 \\
\hline Deney tüpü & \multicolumn{4}{|c|}{ İnsan } & 1 \\
\hline Beyaz önlük & \multicolumn{4}{|c|}{ Bitki } & 1 \\
\hline Olumlu düșünceler & \multicolumn{4}{|c|}{ Olumsuz düș̈̈nceler } & \\
\hline Renkli & \multicolumn{4}{|c|}{ Zor } & 4 \\
\hline Kolay & \multicolumn{4}{|c|}{ Hiç sevmem } & 1 \\
\hline Zevkli & \multicolumn{4}{|c|}{ İğrenç } & 1 \\
\hline & \multicolumn{4}{|c|}{ Gereksiz } & 1 \\
\hline & \multicolumn{4}{|c|}{ Zararlı } & 1 \\
\hline & \multicolumn{4}{|c|}{ Karışık } & 1 \\
\hline
\end{tabular}


Tablo incelendiğinde okul öncesi öğretmen adaylarının zihinlerinde kimya denilince daha çok içerik/konunun, içerik/konu olarak da periyodik cetvel, element, atom ve tepkime kavramlarının şekillendiği görülmektedir. Bununla birlikte az sayıda öğretmen adayının zor, hiç sevmem, iğrenç, gereksiz, zararlı ve karışık gibi olumsuz cevaplar verdikleri saptanmıştır.

Okul öncesi öğretmen adaylarının fizik kavramına yönelik zihinlerinde beliren ilk imgeler Tablo 12'de verilmiştir.

Tablo 12

Okul Öncesi Öğretmen Adaylarının Fizik Kavramına Yönelik Zihinlerinde Beliren Illk Imgeler

\begin{tabular}{|c|c|c|c|c|c|}
\hline İçerik/Konu & & & & & \\
\hline Basit makineler & 23 & Kuantum & 4 & Atom & 2 \\
\hline Kuvvet, hareket & 18 & Moment & 3 & Enerji & 2 \\
\hline Hız, ivme & 15 & Ağırlık & 3 & İş & 1 \\
\hline Yer çekimi & 11 & Vektör & 3 & Güç & 1 \\
\hline Kaldırma kuvveti & 5 & Kanunlar & 3 & Mekanik & 1 \\
\hline Sürtünme kuvveti & 5 & Teori & 1 & Serbest düşme & 1 \\
\hline Çekim kuvveti & 1 & Işık-aynalar & 2 & Etki-tepki & 1 \\
\hline Kütle, hacim, yoğunluk & 12 & Optik & 1 & Yay & 1 \\
\hline Elektrik & 7 & Kırılma & 1 & Manyetizma & 1 \\
\hline Seri bağlama & 1 & Işık hızı & 1 & Gezegenler & 1 \\
\hline Volt & 1 & Dalgalar & 1 & Basınç & 1 \\
\hline Ampul & 1 & Madde & 2 & & \\
\hline Disiplinler arası ilişki & & Uygulama & & Bilim adamı & \\
\hline \multirow[t]{2}{*}{ Matematik } & 12 & Araştırma yapmak & 5 & Einstein & 2 \\
\hline & & Deney & 1 & Newton & 1 \\
\hline Formül & & Olumlu düşünceler & & Olumsuz düşünceler & \\
\hline $\mathrm{e}=\mathrm{m} \mathrm{c}^{2}$ & 2 & Eğlenceli & 1 & Çok zor & 3 \\
\hline $\mathrm{X}=\mathrm{V} . \mathrm{t}$ & 1 & Ufuk açıcı & 1 & Karışık & 1 \\
\hline \multirow[t]{2}{*}{$\mathrm{d}=\mathrm{m} / \mathrm{v}$} & 1 & & & Hiç sevmem & 1 \\
\hline & & & & Zehir & 1 \\
\hline
\end{tabular}

Tablo incelendiğinde okul öncesi öğretmen adaylarının zihinlerinde fizik denilince daha çok içerik/konunun, içerik/konu olarak da basit makineler, kuvvet, hareket, hız, ivme, kütle, hacim, yoğunluk ve yer çekimi kavramlarının şekillendiği görülmektedir. Bununla birlikte az sayıda öğretmen adayının çok zor, karışık, hiç sevmem ve zehir gibi olumsuz cevaplar verdikleri saptanmıştır.

Okul öncesi öğretmen adaylarının biyoloji kavramına yönelik zihinlerinde beliren ilk imgeler Tablo 13'de verilmiştir. 
Tablo 13

Okul Öncesi Öğretmen Adaylarının Biyoloji Kavramına Yönelik Zihinlerinde Beliren Ilk Imgeler

\begin{tabular}{lclllc}
\hline İcerik/Konu & & & & & \\
\hline Canlılar & 27 & Hücre & 12 & Zigot & 1 \\
Bitkiler & 14 & Mitokondri & 7 & Hormon & 2 \\
İnsanlar & 14 & Kloroplast & 3 & Kan & 1 \\
Hayvanlar & 13 & Endoplazmik retikulum & 3 & Kan grubu & 1 \\
Amip & 2 & Ribozom & 2 & Vitamin & 1 \\
Bakteri & 2 & Golgi cisimciği & 2 & Fotosentez & 10 \\
Algler & 2 & Sitoplazma & 2 & Glikoz & 2 \\
Mikroorganizmalar & 1 & Hücre duvarı & 1 & Su & 1 \\
Omurgalılar-omurgasızlar & 1 & Koful & 1 & Güneş & 1 \\
Sürüngenler & 1 & Hücre çeperi & 1 & Yaşam alanları & 1 \\
Memeliler & 1 & Çekirdek & 1 & Popülasyon & 1 \\
Mantar & 1 & DNA & 6 & Madde geçişi & 1 \\
Terliksi hayvan & 1 & Kromozom & 2 & Osmoz & 1 \\
Sinıflandırma & 1 & DNA eşleşmesi & 1 & Difüzyon & 1 \\
Sistemler & 12 & RNA & 1 & Karoten & 1 \\
Organlar & 3 & Kalıtım & 1 & Yasalar & 1 \\
Bölünmeler (mitoz ve mayoz) & 16 & Gen & 1 & Homeostasi & 1 \\
\hline Alt dalları & & Uygulama & & Bilim adamı & 1 \\
\hline Anatomi & 2 & Araşı̆ırma yapmak & 5 & Darwin & \\
Fizyoloji & 1 & Sağlıkla ilgili çalışmalar & 2 & & \\
\hline
\end{tabular}

Tablo incelendiğinde okul öncesi öğretmen adaylarının zihinlerinde biyoloji denilince daha çok içerik/konunun, içerik/konu olarak da canlılar, bölünmeler (mitoz ve mayoz), sistemler, hücre ve fotosentez kavramlarının şekillendiği görülmektedir.

\section{Tartışma, Sonuç ve Öneriler}

Çalışma sonucunda öğretmen adaylarının kimya kavramına ilişkin oluşturdukları metaforların yaklaşık 2/5’inin olumlu, yaklaşık 1/5'inin nötr, yaklaşık 2/5'inin olumsuz olduğu; fizik kavramına yönelik oluşturdukları metaforların 2/5'inden fazlasının olumlu, 1/5'inin nötr ve yaklaşık 3/10'unun olumsuz olduğu; biyoloji kavramına ilişkin oluşturdukları metaforların yarısından fazlasının olumlu, yaklaşık 3/10'unun nötr ve az sayıda olumsuz olduğu saptanmıştır.

Okul öncesi öğretmen adaylarının kimya, fizik ve biyoloji kavramları için zihinlerinde beliren ilk imgelerin kimya için periyodik cetvel ve element; fizik için basit makineler, kuvvet, hareket, hız, ivme, kütle, hacim, yoğunluk ve yer çekimi; biyoloji için canlılar, bölünmeler, hücre, sistemler ve fotosentez olduğu saptanmıştır.

Okul öncesi öğretmen adaylarının kimya kavramına ilişkin ifade ettikleri olumlu metaforların daha çok yaşam ve doğa ile iç içe, eğlenceli, değişen, ilerleyen ve yenilikçi, ihtiyaç, üretken ve kapsamlı; nötr metaforların konu ve içerik, uygulama, kapsamlı ve disiplinler arası ilişki; olumsuz 
metaforların zor ve karmaşık, tehlikeli ve rahatsız edici kategorilerinde yoğunlaştığı görülmüştür. Lise öğrencilerinin ifade ettikleri metaforların da kimyanın yapısı ve işleyişi, olguları anlama aracı olarak kimya, hayatın içinde bir yapı olarak kimya, simyadan kimyaya, sevilen, eğlenceli, kavranabilir bir ders olarak kimya, sevilmeyen, zor ve karışık bir ders olarak kimya kategorilerinde olduğu saptanmıștır (Derman, 2014).

Okul öncesi öğretmen adaylarının fizik kavramına ilişkin ifade ettikleri olumlu metaforların daha çok yaşam ve doğa ile iç içe, denge ve düzen, eğlenceli, değişen, ilerleyen ve yenilikçi, ihtiyaç; nötr metaforların konu ve içerik, kapsamlı ve disiplinler arası ilişki; olumsuz metaforların zor ve karmaşık, tehlikeli ve gereksiz kategorilerinde yoğunlaştığı görülmüştür. Aksakalll, Turgut ve Salar (2016) da çalışmalarında fizik ve fen bilgisi öğretmenliği ile fizik bölümünde öğrenim gören öğrencilerin modern fiziğe yönelik algılarını incelemişlerdir. Öğrencilerin modern fizik ile ilgili algılarını endişe, soyut, ön yargı, yabancılaşma, kavramsal zorluk içermesi, matematiksel zorluk, görselleştirmesinin zor olması şeklinde ifade ettikleri saptanmıştır. Öğrenciler tarafından sıklıkla ifade eden yabancılaşma algısının ise öğretim elemanlarının, ders içi etkinliklerin, öğretim programının, ders kitaplarının etkili olduğu ortaya koyulmuştur.

Okul öncesi öğretmen adaylarının biyoloji kavramına ilişkin ifade ettikleri olumlu metaforların daha çok yaşam ve doğa ile iç içe, ihtiyaç, zevkli, değişen, ilerleyen ve yenilikçi, düzenli, araştırmaya açı; nötr metaforların konu ve içerik ve kapsamlı; olumsuz metaforların zor ve karmaşık kategorisinde olduğu görülmektedir. Benzer şekilde lise öğrencilerinin büyük bir çoğunluğunun biyolojiyi yaşamın kaynağı-yaşamın kendisi, değişen ve gelişen, yaşam alanı ve gereksinim olarak nitelendirdikleri ortaya koyulmuştur (Yapıc1, 2015). Bir başka çalışmada ise fen bilgisi öğretmen adaylarının ifade ettikleri metaforların ise "Kapsamlı bir ders olarak biyoloji”, "Araştırmaya, yeni buluşlara açık olan biyoloji”, Farklı alt dalları olan biyoloji”, "Zor bir ders olarak biyoloji”, "Yaşamın içinde var olan bir ders olarak biyoloji", "Eğlenceli bir ders olarak biyoloji", "Dikkat gerektiren bir ders olarak biyoloji”, "Duruma göre kolay veya zor bir ders olarak biyoloji”, Heyecan verici bir ders olarak biyoloji” algı kategorilerinde olduğu saptanmıștır (Ulukök vd., 2015).

Bu çalışmada kimya, fizik ve biyoloji kavramları için belirtilen olumlu metaforların yaşam ve doğa ile iç içe kategorilerinde yoğunlaştığı saptanmıştır. Benzer şekilde Gürbüzoğlu-Yalmancı ve Aydın (2013) çalışmalarında fen bilgisi ve sınıf öğretmeni adaylarının biyoloji kavramını hayat metaforunu ifade ederek yaşamın kendisi ile ilişkilendirdiklerini saptamışlardır. Yapıcı (2015) da çalışmasında lise öğrencilerinin önemli bir bölümünün biyolojiyi yaşamın kaynağı-yaşamın kendisi olarak nitelendirdiklerini ortaya koymuştur. Alanyazınla da uyumlu olmakla birlikte bu çalışmadan elde edilen bulgular okul öncesi öğretmen adaylarının kimya, fizik ve biyolojinin içerik ve işlev olarak hayatı yansıttı̆̆ını düşündüklerini göstermektedir.

Bu çalışmada kimya, fizik ve biyoloji kavramları için belirtilen nötr metaforların konu ve içerik, olumsuz metaforların ise zor ve karmaşık kategorilerinde yoğunlaştığı saptanmıştır. Benzer şekilde Derman (2014) tarafından yapılan çalışmada lise öğrencilerinin kimya kavramına ilişkin ifade ettikleri metaforların "Sevilmeyen, zor ve karışık bir ders olarak kimya” kategorisinde yoğunlaştığını ortaya koymuştur. 
Okul öncesi öğretmen adayları tarafından kimya kavramı için ifade edilen olumlu ve olumsuz metaforların sayılarının aynı olduğu görülmüştür. Benzer şekilde Dönmez-Usta ve Ültay (2015) da yaptığı çalışmasında okul öncesi öğretmen adaylarının kimya kavramına ilişkin ifade ettikleri olumlu ve olumsuz metafor sayılarının birbirine yakın olduğunu ortaya koymuştur.

$\mathrm{Bu}$ çalışmada kimya kavramı için oluşturulan olumsuz metafor sayısının fizik ve biyoloji kavramları için oluşturulan olumsuz metafor sayılarından daha fazla olması dikkat çekicidir. Biyoloji ve fizik kavramlarında ise olumlu metaforların olumsuz metaforlardan daha çok olduğu; olumlu metaforların sırası ile biyoloji, fizik ve kimya kavramlarına ilişkin olduğu belirlenmiştir. Benzer şekilde Gürbüzoğlu-Yalmancı ve Aydın (2013) çalışmalarında çok az sayıda öğretmen adayının biyoloji kavramına ilişkin olumsuz metaforlar oluşturduğunu ve öğretmen adaylarının "biyoloji" kavramı hakkındaki yargılarının olumlu olduğunu ortaya koymuşlardır. Yapıcı (2015) da çalışmasında lise öğrencilerinin biyoloji ile ilgili olumlu görüşe sahip olduklarını ifade etmiştir. Bunun yanı sıra az sayıda da olsa bazı öğrencilerin olumsuz tutum ve görüşlerini ortaya koyan metaforlar oluşturduklarını belirtmiştir. Ulukök vd. (2015) tarafından yapılan çalışmada da fen bilgisi öğretmen adaylarının biyoloji kavramına ilişkin olumlu ve olumsuz metaforlar oluşturdukları, bununla birlikte olumlu algıların daha fazla olduğu ortaya koyulmuştur.

Okul öncesi öğretmenliği lisans programı incelendiğinde insan anatomisi ve fizyolojisi dersi kapsamında insan vücudu ve işleyişi hakkında temel bilgiler, merkezi ve periferik sinir sistemi, hareket sistemi, duyu organları, dolaşım sistemi, sindirim sistemi, solunum sistemi, boşaltım sistemi, endokrin sistem, üreme sistemi, bu sistemlerin geliştirilmesinin 0-6 yaş dönemindeki önemi konularının işlendiği görülmektedir. Fen eğitimi dersi kapsamında ise fen ve doğanın önemi, okul öncesi dönemde temel fen kavramlarını ve bilimsel düşünme becerilerini öğretme teknikleri, bu tekniklere göre etkinlik ve materyal hazırlama, uygulama, okul öncesi eğitim programlarında fen eğitimi konuları işlenmektedir (YÖK, t.y.). Bu çalışmada görüldüğü üzere okul öncesi öğretmen adaylarının biyolojiye yönelik algılarının fizik ve kimyaya yönelik algılarından daha olumlu olduğu anlaşılmıştır. Bu durum beraberinde öğretmen adaylarının biyolojiye yönelik tutumlarının fizik ve kimyaya yönelik tutumlarına göre daha olumlu olduğu sonucunu doğurmaktadır. Bu sonuç üzerinde lisans programında biyoloji ile ilgili konulara daha geniş yer verilmesinin etkili olabileceği düşünülmektedir. Bu düşünceden hareketle okul öncesi eğitimde fizik ve kimya ile ilgili konulara da geniş yer verilmesi gerektiği önerilmektedir. Bunun yanı sıra elde edilen sonuç üzerinde biyoloji, fizik ve kimya konuları ile ilgili günlük yaşamla kurulan bağlantıların da etkili olabileceği düşünülmektedir. Öyle ki, 4. sınıf fen bilgisi öğretmen adaylarının kimya algılarının incelendiği bir çalışmada kimyanın kapsamının geniş olmasının bir dezavantaj olarak görülmesinin önlenerek bu durumun bir avantaj olarak kabul edilmesinde kimya bilgilerinin günlük yaşamda kullanımının sağlanmasının etkili olacağı savunulmaktadır. Günlük yaşamda kimyadan izler olduğunu gören öğretmen adayının kimyanın yaşamı kolaylaştırdığını fark ederek kimyadan zevk alacağı vurgulanmaktadır. Kimyanın günlük yaşamdaki yerini vurgulayan derslerin kimyaya yönelik alg1 ve beraberinde de ilgiyi olumlu yönde etkileyeceği ifade edilmektedir (Büyükekşi ve Yavuz, 2016). Benzer durumun fizik ve biyoloji dersleri için de geçerli olabileceği düşünülmektedir. Biyoloji, fizik ve kimya alanları konu kapsamı bağlamında geniş, zor ve karmaşık olarak kabul edilse de günlük yaşamla kurulacak zengin bağlantılar ile olumsuz algılar olumlu yönde değiştirilebilir. 


\section{Kaynaklar}

Acay-Sözbir, S., Çamlıbel-Çakmak, Ö. (2016). Okul öncesi öğretmen adaylarının “müzik” kavramına ilişkin metaforik algıları. International Journal of Social Science, 42, 269-282. http://www.jasstudies. com/Makaleler/1538403192_17.\%20Yrd.\%20Do\%C3\%A7.\%20Dr.\%20Senem\%20ACAY\%20 S\%C3\%96ZB\%C4\%B0R.pdf adresinden alınmıştır.

Akınc1-Demirbaş, E. (2015). Çocuk gelişimi bölümü üniversite öğrencilerinin “çocuk” kavramına ilişkin sahip oldukları zihinsel imgeler. Eğitim ve Öğretim Araştırmaları Dergisi, 4(1), 295-303. http:// www.jret.org/FileUpload/ks281142/File/28.akinci_demirbas.pdf adresinden alınmıștır.

Aksakallı, A., Turgut, Ü., Salar, R. (2016). Modern fiziğe karşı negatif algılar ve yabancılaşma algısının nedenleri: Lisans öğrencileri üzerine nitel bir araştırma. Erzincan Üniversitesi Eğitim Fakültesi Dergisi, 18(2), 771-794. http://eefdergi.erzincan.edu.tr/article/view/5000200567/5000178507 adresinden alınmıştır.

Büyükekşi, C., Yavuz, S. (2016). Fen bilgisi öğretmen adaylarının kimya algılarının incelenmesi. Journal of the Turkish Chemical Society, Section C: Chemical Education, 1(1), 107-118. http://dergipark. ulakbim.gov.tr/jotcsc/article/view/5000193595/5000172594 adresinden alınmıştır.

Cerit, Y. (2008). Öğretmen kavramı ile ilgili metaforlara ilişkin öğrenci, öğretmen ve yöneticilerin görüşleri. Türk Eğitim Bilimleri Dergisi, 6(4), 693-712. http://www.tebd.gazi.edu.tr/index.php/tebd/article/ viewFile/177/163 adresinden alınmıştır.

Çamlıbel-Çakmak, Ö. (2014). Okul öncesi dönemde fen eğitimi ve öğretmenin rolü. M. Metin ve Ç. Şahin (Eds.), Örnek uygulamalarla okul öncesi dönemde fen eğitimi içinde, (s. 30-49). Ankara: Pegem Akademi.

Derman, A. (2014). Lise öğrencilerinin kimya kavramına yönelik metaforik algıları. Turkish Studies, 9(5), 749-776. http://www.turkishstudies.net/Makaleler/561028989_42DermanAy\%C5\%9Feg\%C3\% BCl-sos-749-776.pdf adresinden alınmıştır.

Dönmez-Usta, N., Ültay, N. (2015). Okul öncesi öğretmen adaylarının "kimya" metaforlarının karşılaştırılması üzerine bir çalışma. Karadeniz Sosyal Bilimler Dergisi, http://dergipark.ulakbim. gov.tr/ksbd/article/view/5000160171 adresinden alınmıştır.

Ergin, B., Şahin, M., Erişen Y. (2013). Prospective pre-school teachers' perceptions of "child": A study of metaphors. International Journal on New Trends in Education and Their Implications, 4(4) 88-101. http://www.ijonte.org/FileUpload/ks63207/File/08b.ergin.pdf adresinden alınmıştır.

Ertürk-Kara, H. G. (2014). Okul öncesi eğitimi öğretmen adaylarının okul öncesi eğitim kavramına ilişkin metaforları. Erzincan Üniversitesi Eğitim Fakültesi Dergisi, 16(2), 104-120. http://eefdergi.erzincan. edu.tr/article/view/5000034127/5000102005 adresinden alınmıştır.

Giren, S. (2015). Okul öncesi eğitimi öğretmen adaylarının okul öncesi eğitim öğretmeni kavramına ilişkin metaforları. Firat Üniversitesi Sosyal Bilimler Enstitüsü Dergisi, 25(2), 123-132. http://dergipark. ulakbim.gov.tr/firatsbed/article/view/5000172914/5000155939 adresinden alınmıştır.

Giren, S., Durak, E. (2015). Okul öncesi öğretmenlerinin oyuncak kavramına ilişkin metaforik algıları. Bartın Üniversitesi Eğitim Fakültesi Dergisi, 4(2), 561-575. http://buefad.bartin.edu.tr/article/ view/5000143590/5000142049 adresinden alınmıştır.

Giren, S. (2016). Okul öncesi öğretmenlerinin “okul öncesi dönem çocuğu için oyun” kavramına ilişkin metaforları. Eğitimde Kuram ve Uygulama, 12(1), 372-388. http://eku.comu.edu.tr/article/ view/5000152114 adresinden alınmıştır. 
Girmen, P. (2007). İlköğretim öğrencilerinin konuşma ve yazma sürecinde metaforlardan yararlanma durumları. Yayınlanmamış Doktora Tezi, Anadolu Üniversitesi Eğitim Bilimleri Enstitüsü, Eskişehir.

Güder-Yağan, S., Yıldırım, A. (2014). Okul öncesi öğretmeni adaylarının demokrasiye ilişkin metaforları. Adryaman Üniversitesi Sosyal Bilimler Enstitüsü Dergisi, 7(16), 151-170. http://dergipark.ulakbim. gov.tr/adyusbd/article/view/5000041580/5000039108 adresinden alınmıştır.

Gürbüzoğlu-Yalmancı, S., Aydın, S. (2013). Öğretmen adaylarının biyoloji kavramına yönelik metaforik algıları. Mustafa Kemal Üniversitesi Sosyal Bilimler Enstitüsü Dergisi, 10(21), 208-223. http://sbed. mku.edu.tr/article/viewFile/1038000098/1038000017 adresinden alınmıştır.

Kallery, M. (2004). Early years teachers' late concern sand perceived needs in science: An exploratory study. Europan Journal of Teacher Education, 27(2), 147-165. http://www.tandfonline.com/doi/ pdf/10.1080/026197604200023024 adresinden alınmıştır.

Koca, Ş. (2012). The pre-school teacher candidates' metaphorical thinking about the concept of music learning, Cyprus International Conference on Educational Research (CY-ICER-2012)North Cyprus. Procedia-Social and Behavioral Sciences, 47, 1485- 1489.

Kuyucu, Y., Şahin, M., Kapıcıoğlu, O. (2013). Okul öncesi öğretmenlerinin “çocuk” kavramına ilişkin sahip oldukları zihinsel imgeler. Eğitim ve Öğretim Araştırmaları Dergisi, 2(2), 43-53. http://www.jret. org/FileUpload/ks281142/File/05._yasemin_kuyucu_mehmet_sahin_m._osman_kapicioglu.pdf adresinden alınmıştır.

Miles, M. B., Huberman, A.M. (1994). Qualitative data analysis: An expanded sourcebook. (2nd Edition). California: SAGE Publications.

Neslitürk, S., Çamlıbel-Çakmak, Ö., Asar, H. (2014). Okul öncesi öğretmenlerinin “veli” kavramına ilişkin metaforik algıları. Adıyaman Üniversitesi Sosyal Bilimler Enstitüsü Dergisi, 7(18), 679-712. http:// dergipark.ulakbim.gov.tr/adyusbd/article/view/5000071169/5000065624 adresinden alınmıştır.

Osborne, J., Simon, S., Collins, S. (2003). Attitudes towards science: A review of the literature and its implications. International Journal of Science Education, 25(9), 1049-1079. http://www.tandfonline. com/doi/pdf/10.1080/0950069032000032199 adresinden alınmıştır.

Pekdoğan, S., Kanak, M. (2015). Okul öncesi öğretmen adaylarının yaratıcılığa ilişkin algıları: Metafor analizi örneği. Uluslararası Eğitim Bilimleri Dergisi, 2(3), 138-147. http://www.inesjournal.com/ Makaleler/1118663235_id-32-serpilpekdogan.pdf adresinden alınmıştır.

Pesen, A., Kara, İ., Gedik, M. (2015). Çocuk gelişimi bölümü 2. sınıf öğrencilerinin “müdür” kavramına ilişkin metafor algıları. Siirt Üniversitesi Sosyal Bilimler Enstitüsü Dergisi, 4, 39-61. http://susbid. siirt.edu.tr/index.php/susbid/article/view/119/37 adresinden alınmıştır.

Serhatlığlu, B. (2014). Okul öncesi öğretmenliği bölümü öğrencilerinin okul öncesi öğretmenine ilişkin metaforik algıları. Uluslar arası EJER Kongresi Bildiri Özetleri Kitabı, Ankara: Anı Yayıncılık.

Saban, A. (2008). Okula ilişkin metaforlar. Kuram ve Uygulamada Eğitim Yönetimi, 55, 459-496. http:// dergipark.ulakbim.gov.tr/kuey/article/view/5000050616/5000047864 adresinden alınmıştır.

Soysal, D., Afacan, Ö. (2012). İlköğretim öğrencilerinin "fen ve teknoloji dersi" ve "fen ve teknoloji öğretmeni” kavramlarına yönelik metafor durumları. Mustafa Kemal Üniversitesi Sosyal Bilimler Enstitüsü Dergisi, 9,(19), 287-306. http://sbed.mku.edu.tr/article/view/1038000326/1038000160 adresinden alınmıştır.

Şahin-Zeteroğlu, E., Doğan, Y., Taner-Derman, M. (2012). Determining the opinions of preschool and primary school teacher candidates on creativity and metaphorical perception. Educational 
Sciences: Theory and Practice. 12(4), 3135-3152. http://files.eric.ed.gov/fulltext/EJ1003006.pdf adresinden alınmıştır.

Şenel, T., Aslan, O. (2014). Okul öncesi öğretmen adaylarının bilim ve bilim insanı kavramlarına ilişkin metaforik algıları. Mersin Üniversitesi Eğitim Fakültesi Dergisi, 10(2), 76-95. http://dergipark. ulakbim.gov.tr/mersinefd/article/view/5000039980/5000065046 adresinden alınmıştır.

Şimşek, C., Bildirici, Z. (2016). The comparison of the children metaphors of female students in preschool teaching and various branches. International Journal of Humanities and Social Science Invention, 5(4), 26-35. http://www.ijhssi.org/papers/v5(4)/E0504026035.pdf adresinden alınmıştır.

Tok, E. (2015). Okul öncesi öğretmen adaylarının yaratıcılık kavramına ilişkin algılarının metafor analizi yoluyla incelenmesi. International Journal of New Trends in Arts, Sports \& ScienceEducation, 4(2), 1-8. http://www.ijtase.net/ojs/index.php/IJTASE/article/view/416/493 adresinden alınmıştır.

Ulukök, Ş., Bayram, K., Selvi, M. (2015). Fen bilgisi öğretmen adaylarının biyoloji kavramına ilişkin zihinsel imgeleri (Metafor analizi örneği). International Online Journal of Educational Sciences, 7(3), 244259. http://www.iojes.net//userfiles/Article/IOJES_1749.pdf adresinden alınmıştır.

YÖK (t.y.) Eğitim Fakültesi Öğretmen Yetiştirme Lisans Programları. Okul Öncesi Öğretmenliği. http://www. yok.gov.tr/documents/10279/49665/okul_oncesi.pdf/7df366cd-74f9-4e5c-b3af-96482405f8bd adresinden alınmıştır.

Yapıcı, İ. Ü. (2015). Lise öğrencilerinin biyoloji kavramına ilişkin metaforik algıları. Elektronik Sosyal Bilimler Dergisi, 14(55), 139-147. http://dergipark.ulakbim.gov.tr/esosder/article/ view/5000119375/5000134473 adresinden alınmıştır.

Yaşar, Ş. (1993). Okul öncesi eğitim öğrencilerinde fene yönelik duyuşsal özellikler. 9. Ya-Pa Okul Öncesi Eğt. ve Yayg. Semineri, Ankara.

Yıldırım, A., Şimşek, H. (2011). Sosyal bilimlerde nitel araştırma yöntemleri. Ankara: Seçkin Yayıncılık.

Zembat, R., Tunçeli, H. İ. ve Akşin, E. (2015, Mayıs). Okul öncesi öğretmen adaylarının "okul yöneticisi" kavramına ilişkin algılarına yönelik metafor çalışması. Uluslararası Katılımlı III. Çocuk Gelişimi ve Eğitimi Kongresi “Erken Müdahale”. Ankara. 
